University of Pennsylvania Carey Law School

Penn Law: Legal Scholarship Repository

Faculty Scholarship at Penn Law

2006

\title{
Making Visible the Invisible: Strategies for Responding to Globalization's Impact on Immigrant Workers in the United States
}

Sarah Paoletti

University of Pennsylvania Carey Law School

Follow this and additional works at: https://scholarship.law.upenn.edu/faculty_scholarship

Part of the Civil Rights and Discrimination Commons, Economic Policy Commons, Immigration Law Commons, International Trade Law Commons, Labor and Employment Law Commons, and the Social Welfare Commons

\section{Repository Citation}

Paoletti, Sarah, "Making Visible the Invisible: Strategies for Responding to Globalization's Impact on Immigrant Workers in the United States" (2006). Faculty Scholarship at Penn Law. 539.

https://scholarship.law.upenn.edu/faculty_scholarship/539

This Article is brought to you for free and open access by Penn Law: Legal Scholarship Repository. It has been accepted for inclusion in Faculty Scholarship at Penn Law by an authorized administrator of Penn Law: Legal Scholarship Repository. For more information, please contact PennlawIR@law.upenn.edu. 


\title{
Making Visible the Invisible: Strategies for Responding to Globalization's Impact on Immigrant Workers in the United States
}

\author{
Sarah Paoletti*
}

\begin{abstract}
This article explores the impact of globalization on immigrant workers in the United States. Although Congress created programs to provide vocational training services and cash allowances to workers who qualified by virtue of having lost their jobs as a result of the adverse impacts of trade, these programs have done little to assist many of the immigrant workers displaced by shifting labor markets. Through critical revieu of two case studies, the article pursues a more comprehensive understanding of the reasons the system failed these workers, in order to better respond to systematic barriers placed in the way of limited-English proficient immigrant workers seeking retraining and related services. Part I explores the experiences and legal claims of more than 125 limited-English proficient employees of a large mushroom operation in Berks County, Pennsylvania. Part II discusses the ongoing efforts of the members of the Asociación de Trabajadores Fronterizos, a private organization fighting to achieve better working conditions and wages for workers displaced by El Paso's vanishing apparel and textile manufacturing industry. Part III delves further into how notions of citizenship serve as barriers to recognition of the workers as vital and permanent members of an integrated working class in the United States. Ultimately, the article argues for the development of a more comprehensive strategy to identify, evaluate, and overcome those barriers, to ensure that advocacy efforts undertaken are more successful.
\end{abstract}

\section{Introduction: The Impact of Globalization on Immigrant Workers}

Eduardo Ortega came to America with a dream of how much better life would be than it was in Mexico. And, it was. He and his

*Practitioner-in-Residence. American University, Washington College of Law: 1 wish to thank the Indiana Journal of Global Legal Studies for inviting me to participate in the 13th Annual Conference of the Indiana Jounal of Global Legal Studies: Globalization and the New Politics of Labor (Indiana University School of Law-Bloomington, February 11-12, 2(105), and the editors of the loumal for their careful and thoughtful editorial assistance. 
wife ... got good jobs, bringing in a total of $\$ 40,000$ to $\$ 50,000$ annually. They were able to buy a home in Reading and raise their three children comfortably. Then their world collapsed. They are two of the 125 Mexicans who were laid off when Money's Foods U.S. Inc. shut down its Evansville operation in December 2000. Ortega tried to recall the emotions he had felt, but could not describe them in Spanish or English.'

A 55-year-old resident alien, |Glorial Amalguer immigrated to Texas from Guanajuato 30 years ago. She's worked for the past 15 years in the garment industry, the last six of those as a quality inspector for Lee Jeans. "This is the first time I've cver been unemployed. Nothing is more frustrating," Almaguer said, her voice cracking with emotion. $^{2}$

Eduardo Ortega and Gloria Amalguer are among tens of thousands of immigrant workers in the United States forced to respond to sudden unemployment in an era of an increasingly global economy and the resulting shifting labor markets. Increased trade and technological advances, allowing for the mechanization of many jobs, combined with the drive toward cheaper labor costs, have resulted in significant job losses in the agriculture and manufacturing industries throughout the country. ${ }^{3}$ The devastation of the garment industry in El Paso, as well as the losses in the Pennsylvania mushroom industry, are part of a larger national trend of massive relocation by manufacturers to countries with lower wages and more lenient environmental regulations, and provide a microcosm through which to examine this larger phenomenon. ${ }^{+}$

1. Laid off Mexicans Claim Bias in Lausuit, Readrvg EAgl.e (Pa.), Mar. 14, 2003 (on file with wuthor).

2. Left Behind by Trade, Displaced Textile Workers Face Barriers to Better Jobs, SAN Antonıo Express-News, May 3, 2002, at 1 B.

3. See generally U.S. Gen. Accounting ( Ffficf, Trade Adjustment Assistance: Experiences of Six Trade-Impacted Communities (2001), available at http://www.gao.gov/new.items/d01838.pdf.

4. In El Paso, North American Free Trade Agreement (NAFTA) displacement and layoffs resulted in the loss of more than 22,000 manufacturing jobs. Darren Meritz, VF Jeanswear Layoffs Vo Surprise for Workers, El. Paso Times, Sept. 3, 2004, at IA. See also Katherine Yung, Tattered Trade Hopes: El Paso No Longer Believes in N.AFTA After Garment Industry Fades, Jobles: Ranks Mount; The City is Struggling to Create a Future in Tourism, Health Care, Dallas Morning News, Apr. 13, 2003, at 1D. 
Globalization-or global competition--is an oft-cited cause of the burgeoning gap in income distribution between the upper classes and the working poor. In a labor market striving for increased efficiency and decreased costs, industries are decentralizing their operations and outsourcing their labor, resulting in the dislocation of workers in the food harvesting, processing, packing, and manufacturing sectors. Those workers then face choosing between two options: seek more education and additional training and skills in the hopes of obtaining sustainable employment or struggle in low-wage jobs with significantly diminished earnings and benefits. ${ }^{5}$

In anticipation of job losses resulting from increased trade and globalization, and in recognition of the need for workers to adapt to the changing labor market, Congress created the Trade Adjustment Assistance program (TAA) as part of the Trade Act of 1974. "TAA is designed to provide vocational training services and cash allowances for workers who lost their jobs as a result of the adverse impacts of trade. In 1993, Congress created a similar program under the North American Free Trade Agreement (NAFTA) providing the same benefits as those provided under TAA for persons who lost their jobs due to imports from Canada or Mexico or a shift in production to those countries from the United States. But as Mr. Ortega and Ms. Amalguer can attest, the training programs have done little to assist them or their colleagues-immigrant workers with limited-English proficiency. Instead of obtaining the vocational training and education needed to meet the demands of the changing labor markets, they found themselves falling behind, unable to straddle the growing income gap that exists between those employed in minimum-wage jobs and those employed in the increasingly highly technical labor market that demands significant train-

5. See Agustín Escobar Latapí. Int l Org. for Migration \& Econ. Comm 'n for Latin Am. and the Cariebean, Migration and Development in North and Central America: A Sy:THETIC VIEW" (1998) ("|T|he relative numbers of jobs requiring 'medium' levels of qualifications diminished, while there was an increase in the number of jobs available both for the more highly skilled and for those with little training.... Within this latter segment of the labour market. which includes high-turnover temporary jobs, niches have opened up for immigrant workers: since these jobs do not provide any additional benefits to compensate for the relatively low wages they pay, they are likely to be unatractive to the native population." (citation omitted)), available at http://www.rcmss.org/investigacion/synthetic.htm.

6. Trade Act of 1974, Pub. L. No. 93-618, 88 Stat. 1978 (1975) (codified as amended at 19 U.S.C. \$\$2101-2495)(West 1999 \& Supp. 2005).

7. 19 U.S.C.A $\$ \S 2291-2298$ (West 1999 \& Supp. 2005).

8. 19 U.S.C. $\$ 2331$ (2000) (repealed 2002). 
ing and education. After years, in some cases decades, of work ing in jobs that allowed them to join the ranks of the middle class, they are finding themsetves once again on the bottom rung of their climb to achieve the elusive American dream, with fewer apparent opportunities to advance.

As the demonstrations and violent outbursts that occurred in France in late 2005 show, the failure to adequately address the disempowerment and disillusionment of new immigrants can have dire consequences." Second-generation immigrants in France lack employment opportunities and integration as full members of French society, "and their frustration turned to isolated incidents of anger and violence that captured the world's attention. One participant stated he joined in the riots because it was "the only way to get attention from the government. Now maybe there will be some programs for us, some better education. some training, some jobs." It is important not to draw the conclusion that disillusioned immigrants resort to violence, as well as not to overstate the similarities between the situation of the immigrant population in France and those in the United States or elsewhere. "2 But the desire to be provided the tools necessary to achieve meaningful cmployment and a valued role in society resonates in the experiences of immigrants in the United States discussed in this article. While policy makers, advocates, academics, and the business community engage in a cost-benefit analysis of migration and debate immigration policy in an era of increased globalization, we must also consider policies to address the impact globalization has on those immigrants who have reached the end of the migration stream, and now call the United States home.

Through critical review of the experiences of Eduardo Ortega, Gloria Amalguer, and their colleagues in Reading, Pennsylvania and El Paso, Texas,

9. See Colin Nickerson, Behind French Unrest, Cries of Racism, Neglect, Boston Globe, Nov. 13, 2005, at A 1: Mary Sanchez, Immigration Doesn't Breed Violence But Inequality Can, Kansas Citr Star, Nov. 22. 2005, at B5; Elaine Sciolino, Immigrants' Dreams Mix with Fury in a Gray Place Near Paris, N.Y. Times, Dec. 12, 2005, at Al.

10. Sciolino, supra note 9.

11. Nickerson, supra note 9 (quoting Mamadou Konate).

12. Perhaps most significantly, the legal system in France does not recognize discrimination. and there are no legal means by which a person can seek redress for having been denied a job on the basis of national origin. Furthermore, France's approach to immigration is embroiled in its history as a colonial power. See Craig S. Smith, France Faces a Colonial Legacy: What Makes Someone French?, N.Y. Trmes, Nov. 11,2005, at Al. Ironically, the colonial history gives the immigrants in France an advantage over the immigrant workers discussed in this article-those in France speak French, and therefore do not face the same language barriers. 
this article seeks to highlight the possibilities and limitations of the legal system as a tool for addressing the systemic failures of programs designed to aid dislocated workers, failures that arise from a broader societal failure to support the integration of immigrants into the broader community. It is hoped that a review of this nature will provide a starting point for advocates and workers striving to develop comprehensive advocacy strategies to overcome the systemic barriers placed in the way of limited-English proficient immigrant workers secking to benefit from retraining and related services, just as "American" workers do. ${ }^{13}$ Part 11 begins with a study of the experiences of more than 125 LEP individuals who lost their jobs when the large mushroom operation in Berks County, Pennsylvania where they worked shut down its Pennsylvania operations at the end of 2000. Part II.A provides a background of the workforce and what the workers cndured in trying to obtain meaningful vocational training. Part II.B examines the legal claims pursued on behalf of the workers and the means for pursuing them. In particular, it argues that the use of national origin, as currently conceived under the rubric of the Civil Rights Act of 1964, fails to adequately encompass the true nature of language-based discrimination and therefore falls short as a means to redress discrimination against LEP immigrants. Part III discusses the ongoing efforts of members of the Asociación de Trabajadores Fronterizos (ATF), a private organization fighting to achieve better working conditions and wages for workers displaced by El Paso's vanishing apparel and textile manufacturing industry. Part III.A discusses the experiences of the members of the ATF, and Part III.B looks at the race-neutral legal strategy pursued by the ATF, a strategy focused on an outcome-determinative test, to overcome the systemic barriers to receipt of meaningful vocational training. Part IV addresses how notions of citizenship further interfere with the recognition of the workers-particularly those who are limited-English proficient and Mexican born-as vital and permanent members of an integrated working-class United States. In conclusion, the article urges the development of a more comprehensive strategy to identify, evaluate, and overcome those barriers, to ensure that advocacy efforts effectuate positive movement towards the ultimate goal of recognition and inclusion of new immigrants into society.

13. Limited-English proficient (LEP) individuals can be those "who do not speak English as their primary language and who have a limited ability to read, write, or understand English." Let Fvervone Participate--Frequently Asked Questions, http://www.lep.gov/faq.html (last visited Feb. 4. 2006) (website maintained by the U.S. Department of Justice). 
II. The Experience of the Workers of Money's Mushrooms U.S., Inc. in Berks Colnty, Pennsylvania

\section{A. Who Are the Workers and What Challenges Did They Face?}

According to the 2000 U.S. Census data, 9.7 percent of the population in Berks County, Pennsylvania is Hispanic or Latino. ${ }^{\text {It }}$ with the highest concentration of that population living inside the city limits of Reading, Pennsylvania. Reading, home to the group of immigrant workers discussed herein, has seen a rise in the Latino population since 1980, such that Latinos comprise nearly onethird of the total population. ${ }^{15}$ Historically, Puerto Ricans employed in the mushroom industry accounted for almost the entire Latino population. However, as the Puerto Rican population has transitioned into the manufacturing and service industries, Mexican-born workers have filled the open jobs in the mushroom industry, changing the demographic profile of the area. ${ }^{16}$ With regard to languages spoken, 8.09 percent of the population in Reading speak Spanish in the home, and of those, 44.84 percent speak English "less than very well." These demographic statistics provide a context for the discussion to follow regarding the systemic barriers, and in some cases outright hostility, the workers from Money's Mushrooms U.S., Inc. faced in trying to obtain vocational training and job placement services.

Money's Mushrooms U.S., Inc. (Money's) employed approximately 330 workers in their mushroom production, harvesting, and packing operation based in

14. U.S. Census Bureat, Fact Sheet: Berks Countr, Pennsilvania, hetp://factfinder.census. gov/home/saff/main.html? _lang=en (in the text box under "Get a Fact Sheet for your community ..." enter "Berks County" and select "Pennsylvania" from the pull-down menu; click the "go" button) (last visited Nov. 11, 2005).

15. In 2004, the Hispanic and Latino population increased to $11.9 \%$, according to the 2004 AmEr1can Community Survey Highlights Fact Sheet for Berks Counts, Pensisylvania. Id. (Click on the "2004" tab at the top of the fact sheet). Between 1980 and 1990 . Berkis County experienced a greater than $90 \%$ increase in the Hispanic and Latino population. Pa. State Data Ctr., Berks Countr, PA-1990 Census Profile, http://pasdc.hbg.psu.cdu/pasde/Data_d__nformation/ cou_profiles/c011.htm! (last visited Feb. 4, 2006). See also Lillian Escobar-Haskins, Wyomissing Found, Reading and Berks Hispanic Center and Latino Community Study 2 (2001), available at http://www.centrohispano.org/_pdf/latinostudynew.doc.pdf.

16. Escobar-Haskins, supra note 15, at 6.

17. CensusScope, Statistics on Language Spoken at Home and English Language Ability, http:// www.censusscope.org/us/m6680/chart_language.html (last visited Nov. 11, 2005) (based on Census 2000 data). 
Berks County, Pennsylvania until it filed for bankruptcy and closed its doors at the end of 2000. ${ }^{1 \times}$ Nearly 80 percent of the workforce was non- or limited-English proficient and of Mexican national origin, whose primary language was Spanish; almost all were legal permanent residents. ${ }^{19}$ Many had been living in Reading, Pennsylvania and working at the same mushroom operation for ten years, if not longer. A high percentage of them were homeowners with school-aged children enrolled in the local public schools, and both the husband and wife worked at the same company. When Money's announced it was closing its doors, entire families had to determine how to pay for their mortgages, electricity, and children's school clothes, and how to find a job that could provide the same level of wages they had been receiving. Anxious about being without work, more than half of the Money's workers were reabsorbed into industries traditionally supplied by migrant and immigrant labor such as the nearby mushroom companies, food-processing plants, and the landscaping industry, while a handful of others returned to Mexico. ${ }^{20}$ The remaining 125 or more workers enrolled in Berks County CareerLink ${ }^{21}$ in order to receive vocational training and other services they were entitled tounder the Workforce Investment Act and the TAA programs.2 They were eager

18. Money's Foods U.S., Inc. had previously operated as Vlasic Farms, Inc., and prior to that as Campbell Fresh. Complaint Specifications, Workers Comm. of Campbell Fresh v. Berks County Workforce Investment Bd. at 1 n. 1 |hereinafter Complaint Specifications|, reprinted with Press Release, Friends of Farmworkers, Inc., Civil Rights Complaint Filed with U.S. Department of Labor, Charging Pennsylvania and Berks County Agencies with Discrimination against Spanish-Speakers (Feb. 6, 2003), available at http://www.friendsfw.org/LEP/DOL/DOI_Complaint_Feb03.pdf. As Staff Attorney for Friends of Farmworkers, Inc. from 1998-1999 and again from 2000-2003, the author was engaged in the legal representation of the Pennsylvania workers discussed in this article.

19. Id. at 4 .

20. Berks County is home to several other mushroom companies, including Giorgio Mushrooms and Blue Mountain Mushroom company, as well as large meatpacking and poultryprocessing plants (MOPAC and Tyson).

21. PA CareerLink. http//www:pacareerlink.state.pa.us. CareerLink is the one-stop job training and service program under the Pennsylvania Department of Labor and Industry, through which the Bureau of Employer and Career Services and Employment and Training Programs operate.

22. The workers, once certified to receive benefits under the TAA programs, were initially optimistic. Antonio Gutierres \& Jessica Culley, Reading: Neu Opportunitics, Sifmbra (El Comité de Apovo a Los Trabajadores Agricolas (CATA), Glassboro, N.J.), Summer 2001, at 5 ("IThe mushroom workers| are the first group of non-English speaking workers to apply for |TAA vocational trainingl benefits in Pennsylvania. English classes, GED Igeneral equivalency diplomal preparation. on-the-job internships and vocational training are all components of the program created. Workers will receive training in a variety of professions such as: carpenters, plumbers, hair stylists, barbers, truck drivers. electricians. certified nursing assistants, etc. Many workers view this time as an opportunity to prepare themselves for better jobs and to improve their standard of living."). 
for the opportunity to learn English and vocational skills that would put them on the path to a new career outside of the agricultural industry, where they had been working in complete segregation and isolation since arriving in the United States."

The workers and their advocates learned quickly that the Berks County CareerLink and the Workforce Investment Board were not prepared to provide the workers with services, citing the workers" limited-English language capabilities as an insurmountable barrier to either their participation in vocational training or finding employment outside the mushroom industry. ${ }^{2+}$ The system -including staffing, informational materials, and available training - was inaccessible to non-and limited-English proficient individuals, resulting in the explicit and implicit message that English language proficiency was a prerequisite to the provision of any services. ${ }^{25}$ In response to the apparent necessity to learn English, the workers and their advocates initially pushed for the establishment of an intensive English as a Second Language (ESL) program that would meet the demand of the workers and would satisfy the requirements of the Trade Act, mediating betwcen state, federal, and local officials. ${ }^{20}$

Following the institution of an ESL program, the workers unsuccessfully sought language-accessible vocational training that would assist them in their job search. Instead of a shared enthusiasm for the opportunities presented, they encountered the apparently prevailing notion that, because of their limitedEnglish proficiency skills and their failure to have learned English upon first arriving in the United States, vocational training would be an exercise in futility.

23. The workers' optimism was reflected in a newsletter of the Comité de Apoyo a los Trabajadores Agrícolas, a membership-based farmworker support group that had been closely involved with the Money's workers' fight for a union. See supra note 22.

24. See Reading: Injustice Plagues the System, SiEm bra (Fl Comité de Apoyo a Los Trabajadores Agricolas (CATA), Glassboro, N.J.), Spring 2001, at 3 (discussing a system perceived by the workers to be "designed to systematically discriminate against migrant workers," noting the limited bilingua! staff at CareerLink available to help the workers, and the existence of English-only trainings with a requirement for a GED or high-school education). The article further notes that the CarcerLink office offered the workers jobs or training in "low wage or highly dangerous jobs," referring specifically to the initial discussion to provide training for asbestos removal or jobs with a roofing contractor who called Career Link when he learned that there was a large number of Mexicans looking for employment. Id.

25. Complaint Specifications, supra note 18, at 5, 8-9.13.

26. It took four months for the county to develop an Fnglish-language course that could accommodate the large group of workers and that would meet the requirements for training set by the Trade Act. See id. at 10-11. 
According to Edward J. McCann, chicf operating officer for the Berks County Work force Investment Board,

|The situation of the Money's workers| has extreme legal and social sensitivity. They were hardworking, stable people. Most of them are not migrants. Some had been employed there 15 years. What they did not do is learn the basic language, despite their industriousness. There is very little opportunity for them to do anything else..$^{-7}$

In addition to their lack of full English proficiency, the workers' lack of formal education was raised to reinforce the notion that they were not capable of employment outside the mushroom industry or the meatpacking and poultryprocessing plants in the area. ${ }^{2 x}$

Ultimately, CareerLink worked with two vocational training programs to establish language-appropriate training programs serving approximately forty of the initial 125 or more workers who had sought training. The first was a bilingual commercial driver's license program that had previously existed and has continued with apparent success..$^{29}$ The sccond training program, however, rcvealed the perception held by CareerLink, the Workforce Investment Board, and the local training providers regarding the workers' abilities and their socioeconomic rank. Although intended to be a building maintenance program, which the workers believed would allow them to begin new careers as building superintendents, plumbers, electricians, and carpenters, the curriculum was in-

27. Mary E. Young, Ex-Workers Will Continue to Get Help. Reading Times (Pa.), June 1, 2002 (on file with author).

28. See Laürie Ketzenberg. How Much Fnglish Does Maria Need to Give A Manicure: Lessons From a 16-Month VESL Program for Dislocated Farm Workers 13-14 (Aug. 2005) (unpublished manuscript, on file with the author) (noting the quarterly testing of workers using an Englishlanguage assessment tool, and the role that testing plays in "reinforclingl societal power relations"). The workers were testing, on average, at a sixth-grade level. Id.

29. See Merar Bushlin, Pennsylvania Latinos Flock to Truck Driving. Reaning Eagle (Pa.), Jan. 6. 2004 (on file with author) (discussing the hiring of bilingual instructors to open access for the truck driving schools and commercial driver's license applicants to the Spanish-speaking Latino Community). The need is illustrated by the story of Hermenejildo Tinoco, who had lost his job when the Ames Distribution Center in the county closed, and enrolled in a truck-driving school after a failed search for reemployment outside of the mushroom operations in the area. Id. 
stead designed around janitorial services. As one worker noted, "I wanted training to become an electrician. Instead, they taught me how to wash bathrooms."

After two years and the expiration of their unemployment compensation and TAA cash assistance benefits, all but a few of the workers found themselves without meaningful employment or any opportunities beyond those which existed at the time they first lost their jobs. ${ }^{21}$ Having exhausted all informal advocacy options, the workers filed a complaint with the Civil Rights Center of the U.S. Department of Labor, alleging violations of the prohibition of national origin discrimination under Title VI of the Civil Rights Act of 1964 and the Department of Labor's Guidance on Serving Persons with Limited English Proficiency, as well as violations of the antidiscrimination provisions incorporated in Section 188 of the Workforce Investment Act. ${ }^{32}$ More than one and a half years later, the Civil Rights Center undertook a review of the Pennsylvania Department of Labor and Industry and the Berks County CareerLink and Workforce Investment Board, with respect to their compliance with the nondiscrimination and equal opportunity requirements under law. ${ }^{33}$ The Compliance Review report indicated numerous shortcomings in the availability of bilingual staff and services to respond to the

30. Complaint Specifications, supra note 18, at 19. A second course in Culinary Arts was proposed, but rather than offering to provide the students with skills that would allow them to find jobs as cooks or wait-staff, or even provide them with the business background to open their own restaurant in the area as some of them had desired, the training was designed to graduate them with dishwashing and salad-prep skills, for which no training was needed to find employment. Id.

31. Money's Mushroom, Inc., Enrollments as of Nov. 1, 2001 (made available to the author as counsel for the workers).

32. Policy Guidance on the Prohibition Against National Origin Discrimination As It Affects Persons With Limited English Proficiency, 66 Fed. Reg. 4,596 (Jan. 17, 2001). A revised Guidance was published in 2003. See Policy Guidance to Federal Financial Assistance Recipients Regarding the Title VI Prohibition Against National Origin Discrimination Affecting Limited English Proficient Persons, 68 Fed. Reg. 32,290 (May 29, 2003). See generally Exec. Order No. 13,166, 65 Fed. Reg. 50,121 (Aug. 11, 2000), available at http://www.usdoj.gov/crt/cor/Pubs/eolep.htm (calling upon each federal agency and all federally assisted programs and activities to develop a plan consistent with Title VI obligations to guard against national origin discrimination to ensure meaningful access to eligible I.EP individuals).

33. The Civil Rights Center of the U.S. Department of Labor chose to treat the complaint as a request for a review to "determine whether the Pennsylvania Department of Labor and Industry and the Berks County Career Link and Workforce Board were complying with the nondiscrimination and equal opportunity requirements of Section 188 of WIA and Title VI of the Civil Rights Act of 1964, in providing meaningful access to LEP individuals seeking service and benefits administered by thesc entities." Letter from Annabelle T. Lockhart, Dir,, U.S. Dep't of Labor Civil Rights Ctr., to Sarah Paoletti, Practitioner-in-Residence, Wash. Coll. of Law Int'l Human Rights Law Clinic (Nov. 18, 2004) (on file with author). 
needs of the Money's workers. ${ }^{34}$ Yet, despite those shortcomings, the Civil Rights Center failed to find a denial of benefits or services to the Money's workers, and concluded that there was insufficient evidence to find the Money's workers had been discriminated against on the basis of national origin. ${ }^{35}$

The following section explores the constraints of national origin as the basis for challenging language-based discrimination, and how both the antidiscrimination statutes and the limited interpretation thereof gave rise to the Center's ultimate dismissal of the workers' claims.

\section{B. The Limitations of a Legal Strategy under the Title VI Nondiscrimination Rubric}

At the core of the Money's workers'struggle for vocational training was the greater challenge of gaining respect and recognition as legal and permanent members in their community, equally worthy of training benefits and opportunities as the hundreds of "American," English-speaking workers also struggling to adapt after losing their jobs in the manufacturing industry." The Money's

34. Civil. Rights Ctr., L.S. Dep't of Labor, Limited Engilish Proficiency Compliance Review of the Commonwealth of Pennsminania Department of Labor and Industri and Berks County Local Workforce Investment Arfa 3 (200H) (on file with author).

35. Letter from Annabelle T. Lockhart, Dir., U.S. Dep t of Labor Civil Rights Ctr., to Sarah Paoletti, Practitioner-in-Residence, Wash. Coll. of Law Int'l Human Rights Law Clinic (Dec. 2. 2004) (giving notice of final agency action on Complaint No. 03-PA-011) (on file with author).

36. During the initial stages of representing the workers from Money's Mushrooms, we discussed filing a suit in federal court. But the Supreme Court had recently reversed the Eleventh Circuit's decision in Sandoval u. Hagan, 197 F.3d 484 (11th Cir. 1999), rev'd sub nom. Alexander v. Sandoval. 532 U.S. 275 (2001), upholding the District Court's finding of national origin discrimination where the state of Alabama had ceased providing driver's license exams in Spanish, finding no private right of action under the implementing regulations addressing disparate impact discrimination issued pursuant to Section 602 of the Civil Rights Act. The Third Circuit then took it one step further, holding that these claims were similarly not allowed under $\$ 1983$, as Justice Stevens had suggested in his dissent in Sandoval, 532 U.S. at 301 . S. Camden Citizens in Action v. N.J. Dep t of Envil. Prot.. 274 F.3d 71 ( 3 d Cir. 2001) (holding EPA regulations prohibiting disparate impact discrimination unenforceable through a private right of action under \$1983). The Supreme Court's decision in Sandoval and developments in the area of intentional discrimination make it increasingly difficult for plaintiffs to seck redress for discrimination of all varieties, as discussed infra. Part II.B.

37. See Dan Kelly, Laid-Off Workers in Berk. Cotmm. Pa., Take Advantage of Training Program: Readivg EAgLe (Pa.), Feb. 29, 2004 (on file with author) (noting the loss of nearly 8,700 manufacturing jobs in Berks County since 1999 and the retraining for the laid-off workers in areas such as health eare and computer technology). See also. Tony Lucia, Today' Top Employers in Reading, Pa.. Area Different from 10 Years. Ago, Rfading Eagie (Pa.). Jan. 4, 2004 (on file with author) (describing the disappearance of many large manufacturing companies in the area). 
workers were not new to the battle for respect and recognition, but unlike this very public struggle for their benefits entitlement, they had waged a previous campaign in the private legal arena of the workplace. At the time of the plant shutdown, the Money's workers were on the verge of finally gaining legal recognition as workers covered under the Pennsylvania Labor Relations Act and therefore as possessors of collective bargaining rights. "At the heart of that fight was the legal import of their identity as mushroom workers: were they "agricultural workers" and therefore excluded from protection under both the National Labor Relations Act and the Pennsylvania Labor Relations Act, or did they qualify as workers over whom the Pennsylvania Labor Relations Act did have jurisdiction? "While the question regarding their legal identity became moot as to their labor and employment rights when the plant closed, their public identity as former mushroom workers - for which language scrved as the most prominent identity marker - became central in their broader struggle for respect and recognition in their home community.

Lau $v$. Nichols, in which the Supreme Court found a school's practice of providing English-only services impermissible national origin discrimination against non-English-speaking students of Chinese origin in violation of Section 601 of the Civil Rights Act of $1964,{ }^{41}$ provides the foundation upon which courts

38. The Pennsylvania Labor Relations Act, like the National Labor Relations Act, excludes "agricultural laborers" from its jurisdiction. See +3 PA. Cons. STat. AN. \$ $\$ 211.3$ (d); 29 U.S.C. § $152(3)(2000)$.

39. Mushroom workers, like all other agricultural workers, a re not covered by the protections of the National Labor Relations Act, 29 U.S.C. \$152(3) (2000). However, the Pennsylvania Labor Relations Board had long held that mushroom workers were not agricultural workers as defined under the Pennsylvania Labor Relations Act, 43 Pa. Cons. Stat. \$211.3(d) (West 1992), and thus their union rights were protected under state statute. Blue Mountain Mushroom Co. v. Pennsylvania Labor Relations Bd., 735 A.2d 742, 747-48 (Pa. Commw. Ct. 1999). This interpretation of the Pennsylvania Labor Relations Act was hotly contested and litigation was pending before the Pennsylvania Supreme Court at the time of the layoffs, relating specifically to this group of workers' union certification. In July 2001, after it was moot for the Money's workers, the Pennsylvania Supreme Court affirmed the decision of the Commonwealth Court and held that mushroom workers are not agricultural workers and therefore are "employees" as defined by the Pennsylvania Labor Relations Act. Vlasic Farms, Inc. v. Pennsylvania Labor Relations Bd., 777 A.2d 80 (Pa. 2001). Ironically, the complaint that started this litigation was an unfair labor practice charge filed by the union asserting that the employer had violated the Pennsylvania Labor Relations Act by threatening to close the plant if the workers voted for a union. Id. at 81 .

40. Lau v. Nichols, +1+ U.S. 563 (1974) (holding that a school's practice of providing an Englishonly education amounted to impermissible national origin discrimination against non-English speaking students of Chinese origin). 
and federal agencies previously have based language discrimination claims." Unfortunately, the promise of the decision in future antidiscrimination claims has not survived subsequent jurisprudence. In Lau, the Supreme Court relied upon regulations issued by the Department of Health, Education and Welfare pursuant to Section 602 of the Civil Rights Act of 1964, prohibiting recipients of federal funding from "restrict|inglan individual in any way in the enjoyment of any advantage or privilege enjoyed by others receiving any service, financial aid or benefit under the program," or "utilizling|criteria or methods of administration which have the effect of subjecting individuals to discrimination," or have "the effect of defeating or substantially impairing accomplishment of the objectives of the program as respect individuals of a particular race, color, or national origin." +2 Relying on those regulations, the Court concluded the failure to provide language-accessible education violated Section 601 of the Civil Rights Act. The parallels between the discrimination encountered by the Money's workers and that endured by the students of Chinese national origin seem clear: in both cases, English served as the method or criteria that defeated the objectives of the program. In the case of the Money's workers, limited-English proficient persons of Mexican national origin were denied access to vocational training programs designed to allow them to move forward after job losses suffered as the result of trade. As with the California public education programs challenged in Lau, the vocational training programs are federally funded entitlements governed by

41. See Sandoval v. Hagan, 7 F. Supp. 2d 1234, 1280-82 (M.D. Ala. 1998), affd, 197 F.3d 484 (11th Cir. 1999), rev'd on other grounds sub nom. Alexander v. Sandoval, 532 U.S. 275 (2001) (holding no private right of action to enforce disparate impact regulations promulgated pursuant to Section 602 of the Civil Rights Act of 1964). Since Lau, courts and government agencies have recognized language-based discrimination. See United States v. Alcantar, 897 F.2d 436 (9th Cir. 1990); Asian Am. Bus. Group v. City of Pomona, 716 F. Supp. 1328, 1332 (C.D. Cal. 1989); EEOC Guidelines on Discrimination Because of National Origin, 29 C.F.R. $\$ 1606.7$ (a) (2005) ("The primary language of an individual is often an essential national origin characteristic."); 29 C.F.R. \$37.35 (2005) (implementing regulations for nondiscrimination provisions of Work force Investment Act of 1998, $\$ 188,29$ U.S.C. $\$ 2938$ (2000)); Department of Justice Guidance to Federal Financial Assistance Recipients Regarding Title VI Prohibition Against National Origin Discrimination Affecting Limited English Proficient Persons, 67 Fed. Reg. 19,237 (Apr. 18, 2002): Department of Labor Policy Guidance to Federal Financial Assistance Recipients Regarding the Title VI Prohibirion Against Xational Origin Discrimination Affecting Limited English Proficient Persons, 68 Fed. Reg. 32,290 (May 29, 2003).

42. Lau, 414 U.S. at $567-68$ (quoting 45 C.F.R. \$ 80.3(b)(1)(iv), (b)(2) (2005), the Court declines to address the Equal Protection Clause argument, resting its decision solely on Section 601 of the (ivil Rights Act of 1964 and the implementing regulations). 
agency regulations and guidelines." Those guidelines specifically obligate federally funded programs to provide language-appropriate services to ensure that ncither intentional nor disparate impact national origin discrimination results. ${ }^{\text {H }}$

Since the Lau decision by the Supreme Court in 1974, new challenges have arisen to legal attempts to combat language-based discrimination. Through its decision in Alexander v. Sandoval, the Supreme Court removed an individual's private right of action to challenge disparate impact discrimination under regulations promulgated pursuant to Section 602 of the Civil Rights Act, despite the Court's earlier precedent under Lau. ${ }^{\text {t5 }}$ The plaintiffs in Sandoval sought to compel the Alabama Department of Public Safety to administer the driver's license test in languages other than English, arguing that the failure to do so constituted unlawful discrimination on the basis of national origin against those who were not fully English proficient. ${ }^{\text {to }}$ In a dramatic shift from the Supreme Court's decision in Lau, in which the implementing regulations served as the basis for mandating language-accessible education, the majority in Sandoval took as a given that Section 601 of the Civil Rights Act covered only intentional discrimination, ${ }^{47}$ forcing plaintiffs to prove either that language requirements exist solely as a pretext for intentional discrimination or forego judicial remedies, pursuing instead administrative remedies through the funding agencies.

In the aftermath of Sandoval and its progeny requiring a showing of intentional discrimination, it is all the more critical to understand how language serves as a proxy for national origin, race, culture, and ethnicity, and to prove how language-based discrimination serves as a pretext for national origin dis-

43. 29 C.F.R. $\$ 37.35$ (2005) (implementing regulations for nondiscrimination provisions of the Workforce Investment Act of 1998, \$188, 29 U.S.C. $\$ 2938$ (2000)); Guidance to Federal Financial Assistance Recipients Regarding Title VI Prohibition Against National Origin Discrimination Affecting Limited English Proficient Persons, 67 Fed. Reg. 19,237 (Apr. 18, 2002); Policy Guidance to Federal Financial Assistance Recipients Regarding the Title VI Prohibition Against National Origin Discrimination Affecting Limited English Proficient Persons, 68 Fed. Reg. 32,290 (May 29, 2003).

44. See sources cited supra note 43 .

45. Sandoval, 532 U.S. at 293.

46. Id. at 279. Importantly, the Court explicitly did not address the validity of the regulations pertaining to language and national origin discrimination, reaching only the issue as to whether an individual has a private right of action to sue under the implementing regulations issued pursuant to Section 602 of the Civil Rights Act. Id.

47. Id. at 280-81 (citing Regents of Univ. of Cal. v. Bakke, 338 U.S. 265 (1978): Guardians Assn. v. Civil Serv. Comm 'n of New York City, 463 U.S. 582 (1983); Alexander v. Choate, +69 U.S. 287 $(1985))$. 
crimination or other forms of invidious and unlawful discrimination such as race and ethnicity discrimination, particularly when that language-based discrimination is applied toward Spanish-speaking Latinos. ${ }^{48}$

The experiences of the Money's workers reveal the inadequacy of national origin as a category to recognize or encompass the multifaceted nature of discrimination - in this case, discrimination arising out of the workers' status as Mexican-born immigrant former-farm workers with limited-English proficiency and limited formal education. ${ }^{47}$ Deemed "industrious," "hard-working," and good employees, ${ }^{511}$ the Money's workers were also viewed as illiterate, uned-

48. The defendants argued before the District Court in Sandoval v. Hagan:

Language is not equivalent to national origin, and the plaintiffs cannot make it so by affidavit. A showing that one of the plaintiffs speaks Spanish does not show which country that plaintiff is from. Is the Department discriminating against that plaintiff because she is from Spain? Mexico? Argentina? or one of a number of other nations: Conversely, some applicants who do not appear to speak English fluently, nonetheless, pass the English-language examination. The classification does not distinguish on the basis of language per se. but rather on the basis of something else. Plantiffs assert that the "something else" is language proficiency but knowledge of the tested material may also be at work and cannot be excluded.

TF. Supp. 2d at 1278-79 (quoting Defendant's Reply to Plaintiff's Opposition to Defendant's Motion for Summary Judgment at 13, Hagan, 7F. Supp. 2d 1234 (No. Civ.A. 96-D-1875-N)). The Court rejected the notion that national origin discrimination must be based on a single specific country or origin, but instead held: "|w|hatever foreign country they may be from, an Englishonly rule would have a disparate impact on the basis of their national origin." Id. at 1279. See also Edward M. Chen, Garcia v. Spun Steak Co.: Speak-English-Only Rules and the Demise of Workplace Pluralism, I Astan L.J. 155, 165 (noting the correlation betwcen language and its "corresponding national origin group," but also recognizing that, "in one respect, the relationship between language and ethnicity is more specific for Asian Pacific Islanders than for Latinos. Given the myriad of tsian languages, each peculiar to a particular country of origin, language is an integral part of an . Asian Pacific Islander's specific national origin identity." (footnote omitted)).

49. Sec Juan F. Perea, Ethnicity and Prejudice: Reevaluating "National Origin" Discrimination Linder Title [II, 35 WM. \& MARY L. REv. 805 (1994) (offering a critique of national origin discrimination as an effective approach to combat discrimination, arguing the actual basis for discriminatwon is often not the individual's country of origin, but rather their perceptible ethnic traits, such as language, and notes the absence of an explicit basis for finding discrimination on the basis of those traits).

50. Young, supra note 27 (quoting Edward). McCann. Chief Operating Officer for the Berks County Workforce Investment Board, referring to the workers as "hardworking" and "industrious"). See also Kevin R. Johnson, Immigration and Latino Identity, 19 Chicano-Lativo L.. RFv: 197. 199 (1998) (referring to Los Angeles employers" preference for "docile Mexican immigrants." and citing lack Miles, Blacks vs. Broums. Antante MoNthix; Oct. 1992, at +1). 
ucated, and unskilled. "The inadequacies of national origin as the lens through which to look at language-based discrimination reveal themselves in Title VII national origin claims arising from "English-only" rules in the private sphere of the work place. ${ }^{52}$ While courts have recognized the central role language plays in one's ethnic, ancestral, and racial identity, and have recognized that language can serve as a proxy for national origin, ${ }^{53}$ they are reluctant to treat language-or accent-based restrictions, regulations, or criteria as prohibited discrimination under Title VII of the Civil Rights Act. ${ }^{54}$

Professor Christopher David Ruiz Cameron has argued that courts' failures to view "English-only" rules in the workplace as national origin discrimination can be blamed on three interrelated issues: the existing racial dualism that fails to see beyond the black and white paradigm, treating the United States as a country of just two races, rather than one of many races and ethnicities; the related and invisible nature of Latinos under the law; and the legal indeterminacy surrounding national origin discrimination under Title VII. ${ }^{55}$ The denial of services to the Money's workers, due to their purported failure to assimilate by learning English, and the pressure placed upon them to accept jobs in the segregated industries of mushroom harvesting, poultry processing, meatpacking, and janitorial services support his analysis regarding the invisibility of Latinos under

51. Mary E. Young, Official: Mexicans Get Equal Treatment, Readrng Eagle (Pa.), Mar. 14, 2003 , at B3.

52. The EEOC states the nexus between language and national origin as follows: "The primary language of an individual is often an essential national origin characteristic." 29 C..F.R. $\$ 1606.7$ (a) (2005).

53. " $|\Lambda|$ ccent and national origin are obviously inextricably intertwined ...." Odima v. Westin Tucson Hotel Co., 991 F.2d 595, 601 (9th Cir. 1993) (quoting Fragante v. City \& County of Honolulu, 888 F.2d 591, 596 (9th Cir. 1989)). See also Carino v. Univ. of Okla. Bd. of Regents, 750 F.2d 815 (10th Cir. 1984) (involving an individual with a noticeable Filipino accent unlawfully demoted from his position as a supervisor and not considered for a supervisory position in a new facility); Garcia v. Gloor, 618 F.2d 26+, 270 (5th Cir. 1980) ("[T|o a person who has difficulty using another language than the one spoken in his home, language might well be an immutable characteristic like sk in color, sex or place of birth."); EEOC v. Premier Operator Servs., Inc., 113 F. Supp. 2d 1066 (N.D. Tex 2000); Saucedo v. Bros. Well Serv., Inc., 464 F. Supp. 919 (S.D. Tex. 1979).

54. See, e.g., Kania v. Archdiocese of Philadelphia, 14 F. Supp. 2 d 730 (E.D. Penn. 1998); Garcia v. Spun Steak Co., 998 F.2d 1480 (9th Cir. 1993); Gloor, 618 F.2d 264.

55. Christopher David Ruiz Cameron, Hou' the Garcia Cousins Lost Their tecents: Understanding the Language of Title VII Decisions. Approving English-Only Rules as the Product of Racial Dualism, Latino Invisibility, and Legal Indeterminacy, 85 CaL. L. Rev. 1347, 1355-56 (1997). 
the law. ${ }^{5 t}$ The legal indeterminacy of national origin discrimination under Title VII, the failure of courts and administrative agencics to adequately grapple with this legal indeterminacy, and their failure to recognize the complexity of discrimination in a multiracial, multiethnic, and gendered society, results in a legal system that, in its inability to redress the discrimination, instead sanctions the invisibility of Spanish-speaking workers. As Professor Ruiz Cameron notes, "Spanish language is central to Latino identity," both as a "fundamental aspect of ethnicity" and as the "historic basis upon which Anglo society discriminates against Latinos." In addressing language-based discrimination, therefore, it is important to move beyond the existing legal compartmentalization of discrimination against Latinos, particularly Spanish-speaking Latinos, as national origin discrimination. ${ }^{.1}$ Discrimination against Latinos is more complex than the national origin framework allows, and one must also examine the role of race, ethnicity, and alienage."

As Professor Perea argues, "most of the discrimination faced by ethnic minorities is based on their perceptible traits, and not on place of birth," including

56. Id. at 1373-74. "A cruel irony for Latinos is that, when we are not being criticized for refusing to stay in line, we are being criticized for refusing to assimilate. 'Latinos persistence in maintaining cultural ties, especially language, is often fodder for conservatives cannons /sic/against the immigration of Mexicans and Latin Americans to the United States. Properly understood, however, this 'refusal to assimilate' is just another way of complaining that we refuse to remain invisible." Id. (footnotes omitted).

57. Id. at 1364: see Gutierrez v. Mun. Court, 838 F.2d 1031. 1039 (9th Cir. 1988) ("The cultural identity of certain minority groups is tied to the use of their primary tongue.").

58. Cameron, supra note 55 , at 1364 .

59. Id. at 1365 .

60. In critiquing the Ninth Circuit's decision in Gatcia v. Spun Stcak Co., 998 F.2d 1480 (rejecting a challenge to an employer's English-only rulc). Edward Chen. counsel for the plaintiffs in the case, similarly restricts his analysis to his perception of the court's failure to properly view national origin discrimination. Chen. supra note 48 , at 175.

61. See Perea, supra note 49. at 835 (identifying language as an "cthnic trait|]" and arguing that discrimination "is more likely to occur aganst persons because of the perceptible manifestations of ethnic distinction, ethnic traits, than because of the often imperceptible fact of national origin"). The argument put forward regarding the need for recognition on the basis of ethnic traits nay be a response, at least in part, to the courts evisceration of protections against disparate impact discrimination through the refusal to grant individuals a private right of action to sue under such a theory. Disparate impact theories were central to cases seeking to draw the link between language and national origin discrimination. See generally id. at 834-ti); I uan F. Perea, Essay. Los (Jividados: On the Makmg of Inwsible People. 70 N.Y.L. 1. REv. 965.981-8s (1995) (arguing for recognition of ethnicity under Title VII). See also infra note 64. 
traits such as race, alienage, language, and culture. If civil rights statutes are going to protect against and provide redress for discrimination faced by ethnic minorities, he contends, they must explicitly recognize ethnic traits. ${ }^{\text {st }}$ Such an approach provides a more responsive strategy less fraught with the tangles of conflated categories of discrimination inadequately addressed within the confines of a national origin framework. ${ }^{t 5}$ In the context of the Money's workers, such an approach would detangle the pretextual arguments that English is a necessary and legitimate prerequisite to vocational training and job-placement assistance from the resulting discrimination against Latino workers. The grant of full recognition of discrimination based on ethnic traits provides a truer method to remedy the invidious nature of language discrimination without hav-

62. Language discrimination against Spanish speakers may be more closely associated with race than with country of origin. In Hemandez $v$. Net' York, 500 U.S. 352 (1991), the petitioners challenged the exclusion of bilingual Spanish-speaking jurors as discrimination on account of race. While accepting the race-neutral explanation proffered by the prosecutor, the Court noted in dicta:

IWle do not resolve the more difficult question of the breadth with which the concept of race should be defined for equal protection purposes. . . It may well be, for certain ethnic groups and in some communities, that proficiency in a particular language, like skin color, should be treated as a surrogate for race under an equal protection analysis.

Id. at 371. See also Gloria Sandrino-Glasser, Los Confundidos: De-Conflating Latinos/as' Race and Ethnicity, 19 Chicano-Latino L. Rev. 69, 137-42 (1998). The conflation of race and national origin vis-à-vis Latinos and the confusion of identities are evidenced in the results of the U.S. Census Bureau. See U.S. Census Bureau Guidance on the Presentation and Comparison of Race and Hispanic Origin Data (June 12, 2003), http://www.census.gov/population/www/socdemo/ compraceho.html; Arthur R. Cresce et al., Identification of Hispanic Ethnicity in Census 2000: Analysis of Data Quality for the Question on Hispanic Origin 11-13 (U.S. Census Bureau, Working Paper No. 75), available at http://www.census.gov/population/www/documentation/ twps0075/twps(0075.pdf.

63. Alienage discrimination is not addressed in the Civil Rights Act of 1964. See 42 U.S.C. $\S$ 2000d (2000); Espinoza v. Farah Mfg. Co., 414 U.S. 86, 88 (1973) (holding refusal to hire a person of Mexican national origin who is not a U.S. citizen permissible under Title VII, particularly where the majority of employees were naturalized U.S. citizens of Mexican national origin and there was no showing of national origin discrimination).

64. See Perea, supra note 61, at 983 (noting that "ethnicity refers to physical and cultural characteristics that make a social group distinctive, either in group members' eyes or in the view of outsiders," and identifying the following partial list of traits that are incorporated in ethnicity: "race, national origin, ancestry, language, religion, shared history, traditions, values, and symbols, all of which contribute to a sense of distinctiveness among members of the group").

65. See Sandrino-Glasser, supra note 62, at 147-56. 
ing to stretch the boundaries of the national origin rubric under either a disparate impact or intentional discrimination theory. ${ }^{60}$

\section{The Experience of the Members of the Asociación de Trabajadores Fronterizos, El Paso, Texas}

\section{A. Who are the Workers and What Challenges Did They Face?}

After years of negotiation, litigation, and mediation undertaken to obtain meaningful and language-accessible vocational training, members of the Asociación de Trabajadores Fronterizos (ATF) have succeeded where the Money's workers failed. On January 6, 2006, the ATF and their lawyers announced a comprehensive settlement agreement with the U.S. Department of I Labor, the Texas Workforce Commission, and El Paso's Upper Rio Grande Workforce Development Board to adequately address the vocational training needs of limitedEnglish proficient individuals. "To appreciate the magnitude of the settlement and its potential for the ATF members and others similarly situated, it is important to understand the context in which and the manner by which success was achieved.

The ATF members share many demographic and experiential commonalities with the Money's workers. They are Mexican-born, limited-English proficient individuals, with limited formal education and a limited work history. In their struggle to receive vocational training that would result in meaningful employment, they encountered the perception that language and educational background were insurmountable barriers. ${ }^{\circ 8}$ Unique to the ATF members, though,

66. See Garcia v. Gloor, 618 F.2d 264, 269 (5th Cir. 1980) ("National origin must not be confused with ethnic or sociocultural traits or an unrelated status, such as citizenship or alienage or poverty, or with activities not connected with national origin, such as labor agitation." (citations omitted)). But it is worth noting that the court also stated that "It the refusal to hire applicants who cannot speak English might be discriminatory if the jobs they seek can be performed without knowledge of that language." $1 d$. Such a situation is one more analogous to that which workers seeking job training and placement services face. See discussion supra Part H (regarding Mexicans and alienage discrimination).

67. Press Release, Pub. Citizen, In Settlement. Department of Labor Agrees to Provide Required Job Training to Workers Whose Jobs Were Outsourced: Lawsuit Alleged That Government Broke Law by Approving Training That Failed to Meet Statutory Requirements (Jan. 6, 2006), available at http://www.citizen.org/pressroom/release.cfm:ID =2100.

68. Edward J. McCann. Chief ()perating Officer for the Berks County Workforce Investment Board, in speaking about the Money's workers, stated: "There is very little opportunity for them to do anything else." Young. supra note 27. 
was the singly-oriented economy in which they worked - the labor market in F:I Paso was based almost exclusively in the garment and apparel manufacturing industry." In recent vears, El Paso has earned the unfortunate distinction as the city with the largest number of NAFTA-related job losses in the nation. "Those who suffered most are workers like the members of the ATF. who-like the workers in Pennsylvania's mushroom industry-are overwhelmingly of Mexican national origin and are limited-English proficient. The industry, once drawn to the area because of the availability of cheap labor, is now moving to Mexico and beyond, in search of cheaper labor and even lower production costs. The sad and difficult irony is that the employees left behind are workers who left Mexico to make Texas their new home in response to the labor demands of the industries that have been leaving over the past decades.

69. Also distinguishing the situation of the Money's workers and the members of the ATF were the demographics of the community in which they lived. Aceording to the U.S. Census Bureau, EI Paso County is 78.2\% Hispanic. U.S. Census Bureau, FI Paso County QuickFacts, http:/quickfacts. census.gov/qfd/states/48/481 41 .html. Of these, $83.3 \%$ are of Mexican national origin. Betsy Guzmá, U.S. Census Bureau, Census 2000: The Hispanic Population 7 n. 14 (2001), available at http://www.census.gov/prod/2001 pubs/c2kbr0l-3.pdf. () El Paso's residents, $68.9 \%$ speak Spanish at home. Hron B. Shin \& Rosalind Breno, U.S. Censts Bureac, Census 2000: Language Use and ENGlish Speaking ABILITY: 2000, at 9 (2003), atailable at http:/www.census.gov/prod/ 2003 pubs/c2kbr-29.pdf, while 32\% speak English "less than very well." Profile of Gencral Demographic Characteristics, County of El Paso, Texas, Census 26)0. http://www.elpasotexas.gov/planning _documents/county_demographic_profile_2000.pdf. This is in sharp contrast to the make-up of Berks County, Pennsylvania, home of the Money's workers, which is just $9.7 \%$ Hispanic. U.S. Census Bureau, Berks County QuickFacts, http:/quickfacts.census.gov/qfd/states/42/42011.html.

70. U.S. Gen. Accounting Office, supra note 3, at 56: see also Memorandum in Support of Plaintiffs Motion for Summary Judgment at 2, Ascciacion de Trabajadores Fronterizos v. U.S. Dep t of Labor, No. EP-04-CA-400-FM (W.D. Tex Nox. 5. 2004) (noting El Paso has endured approximately five times more NAFTA-related job losses than any other city in the United States, with nearly 20,000 workers losing their jobs) (on file with author).

71. Within the job losses in the garment industry, nearly $95 \%$ of the workers are of Mexican national origin and $65 \%$ are female. Memorandum in Support of Plaintiffs Motion for Summary Judgment, supra note 70 , at 2.

72. Charlie LeDuff, Mexican-Americans Struggle for Jobs. N.Y. Ttmes, Oct. 13, 2004, at A14 ("In a strange post-industrial twist, most people who have lost their jobs in the garment industry here are first-generation Mexican women. ... They came to El Paso in the 60's, 70's and 80's, when the American factories moved down from the Vorthern states in search of cut-rate border labor. ... With those factories having moved out of El Paso, these American citizens find they are members of the obsolescent class."). 
Unlike the Money's workers, who largely could be reabsorbed into the mushroom industry, ${ }^{73}$ the ATF members were left with rapidly dwindling opportunities to find new employment in the garment and apparel manufacturing industry they knew because the jobs simply no longer existed. ${ }^{\text {it }}$ The resulting plight of those employees is illustrated through the tales of women, like Ms. Amalguer, mentioned above, and Ernestina Miranda. Miranda came to the United States in 1979 and became a citizen in the late 1980s. In response to the move to her country of origin of the industry that brought her here, she laments, "My American dream has turned into a nightmare."

In 1998, the federal government singled out El Paso as "one of the best examples of a community greatly impacted by job losses due to industry relocation ...characterized by high unemployment and an older workforce lacking in English proficiency, marketable job skills, and a formal education, but with a very strong work ethic and a desire to better themselves and their community." As a result of the industry relocation, approximately 2,000 limited-English proficient workers, all members of the ATF, have qualified for benefits under TAA and have sought language-accessible training." Unfortu-

73. While this ultimately became the default option for many of the Money's workers because of the failure to provide vocational training and other reemplovment services, it was not a solution. As discussed, many of the workers reemployed in the mushroom industry did not choose to return to mushroom work of their own volition but rather out of necessity, and they are earning significantiy less than their previous earnings at Money's Mushrooms, Inc.

74. See U.S. Gen. Accotnting Office, supra note 3, at 5; ("The Chief Executive Officer of the Upper Rio Grande Workforce Development Board said that in prior years, garment workers had alwavs been able to get a job in another plant. By the summer of 1998 , he said that there was virtually nowhere to go for a new apparel job."); Vic Kolenc. VF Jeanswear Lays off 395 , E1. PAso Times, July 19,2005, at $1 \mathrm{~F}$ (quoting Sam Tucker, vice president of Human Resources at VF Jeanswear's headquarters in Greensboro, N.C.: "The economic reality is the apparel industry has basically left the United States."); David Crowder. Soon-to-Be-Displaced Workers Worried About Training, FL PAso Trmes, Sept. 15, 2004, at +B (quoting (;uillermo Glenn, coordinator of the ATF. telling the El Paso City Council members that " $/ \mathrm{m}$ Jore than 10.000 workers have lost jobs in three years").

75. LeDuff. supra note 72 .

76. President's Inter-Agency Task Force on the Ficon. Dev. of the Sw. Border, lnterim RePORT 57 (1999), atailable at http://wwwtreas.gow/press/releases/reports/border.pdf. The report characterized the dislocated workers as "largely female, between the ages of 35 and 45 . with 10 to 15 years of experience working in the garment industry, and though some have a GED or high school diploma, most have only a limited education. In addition, most have a very limited abiliry to speak Finglish." Id. at $6(t)$.

77. Ser Memorandum in Support of Plaintiffs Motion for Summary Judgment. supra note 70. at 3. 
nately, as the Money's workers learned in their experience and as the Texas Workforce Commission purportedly explained:

IT the federal trade program's guidelines originally designed to assist middle-age, middle-class. English-speaking factory workers in the Midwest and northeast, were simply extended to the NAFTA trade affected workers on the Texas-Mexico border with little adjustment to compensate for the significant differences in the populations of these economically, culturally and geographically divergent areas."

Instead of adapting the program to meet the needs of the population described above, the Texas Workforce Commission established remedial ESL and general equivalency diploma (GED) courses. What the ATF members quickly learned was the lesson later to be learned by the Money's workers: ESI and GED programs fail to meet the training goals of TAA - the programs do nothing to increase the marketability of the workers in the dramatically changing economy. Like their counterparts in Pennsylvania, the workers wanted and needed more meaningful vocational training to find stable employment in the changing economy.

The outcome for the majority of ATF members enrolled in the ESL and GED programs demonstrates the deficiencies in a training program geared toward linguistic assimilation as a mandatory first step toward obtaining any meaningful vocational training and future job opportunities. ${ }^{81}$ Individuals who completed the available ESL and GED training programs in the time allotted by their Trade Act benefits suffered a three- to eight-dollar hourly wage loss. ${ }^{82}$ The diminished wages received by the ATF members able to find employment fol-

78. Id. at 7. See generally Steven Greenhouse, Start a New Career at 50? In Syracuse, Life After Layoffs, N.Y. Trmes, June 20,2005, at B1 (showing the program at work in the northeast).

79. Cf. Memorandum in Support of Plaintiffs Motion for Summary Judgment, supra note 70, at 5 (stating that "the TAA's only stated purpose has been to enable trade-dislocated workers to "return to suitable employment" ' and citing 20 C.F.R. $\$ 617.2(200+))$.

80. See id. at 11.

81. Cf. id. at I (alleging that "Congress created Trade Act training as a uniform federal remedy for trade-dislocated workers, but DOL provides LEP workers with cheap remedial education instead of the bilingual vocations training that these workers need to find replacement jobs after the North American Free Trade Agreement (NAFTA) eliminated their livelihoods").

82. Id. at 27 . 
lowing their participation in the ESL and GED serial training programs vividly illustrate the shortcomings of providing training aimed exclusively at English proficiency. The wage loss and lack of programs to address that wage loss are emblematic of a greater struggle - a struggle to be viewed as valued members of the community, able to learn and able to profit from meaningful job training. ${ }^{.3}$

The ATF and its members spent approximately eight years trying to work with the El Paso Upper Rio Grande Workforce Development Board, the Texas Workforce Commission, and the U.S. Department of Labor to address the need for bilingual vocational training that would assist its members in finding meaningful employment in light of El Paso's changing labor market economy, resulting from changes globally in the garment and apparel industry. ${ }^{x+}$ During those years, the ATF filed a complaint with the Civil Rights Center of the U.S. Department of Labor and, like the Money's workers, was unsuccessful in its attempts to bring about positive changes in the services provided through that process, and subsequently filed suit in federal court alleging national origin discrimination in April 2001. ${ }^{5}$ The ATF then filed a second federal lawsuit against the U.S. Department of Labor, the Texas Workforce Commission, and the El Paso Upper Rio Grande Workforce Development Board, alleging violations of the Trade Act requirements that the training programs be designed to ensure that a participant find meaningful employment upon completion. ${ }^{\mathrm{s}}$

\section{B. The National Origin and Race-Neutral Approach}

Following unsuccessful attempts to force the local, state, and federal agencies to provide vocational training beyond remedial ESL and GED courses, counsel to the members of the ATF shifted to a national origin and race-ncutral advocacy strategy focused on output measurements of training provided under the Trade Act. ${ }^{57}$ Rather than continuing to challenge the discriminatory impact of the Texas Workforce Commission's failure to provide adequate bilingual

83. Sec discussion infra Part 111.

84. Memorandum in Support of Plaintiffs Motion for Summary Judgment, supra note 7), at $27-28$.

85. Interview with Jerome W. Wesevich. Counsel for Asociación de Trabajadores Fronterizos. in Washington, D.C. (Dec. 2. 2004).

86. Those cases were consolidated and sent to medi: tion. Telephone Interview with Jerome W: Wesevich. Counsel for Asociación de Trabajadores tronterizos, in Washington. D.C. (Aug. 1. $2005)$.

87. See Memorandum in Support of Plaintiff's Motion for Summary Judgment, supra note 70. 
training beyond remedial ESL and GED under Title VI, the ATF alleged the U.S. Department of Labor failed to meet its obligations under the Trade Act by failing to issue appropriate guidance and oversight to ensure that the goal that workers be prepared to return to "suitable employnent" upon completion of their training was met. The ATF contended that "suitable employment" means employment at a minimum of 80 percent of the worker's earnings ${ }^{511}$ prior to suffering a trade-impacted job loss.

The settlement is a watershed moment for limited-English proficient dislocated workers, particularly those in El Paso. It provides that state agencies must work to enable trade-dislocated workers to obtain employment that will pay a minimum of 80 percent of their former income - a goal set by Congress but previously waived for Texas, purportedly because of the cost associated with providing the training necessary to achieve such a goal. The settlement specifically mandates that limited-English proficient workers in El Paso have the choice to select: a vocational training course geared towards job-ready occupations in accordance with the Workforce Board's Demand or Targeted Occupation Lists; customized training needed for a particular job offer that a participant may have; on-the-job training; and remedial education such as ESL, GED, and basic computer skills "only to the extent necessary to enable a worker to complete a specific vocational or |on-the-job training|, or when an assessment shows that remedial education is all that a participant needs to form a complete skill set needed for a specific target occupation." The U.S. Department of Labor and the Texas Workforce Commission have committed six million dollars toward development and provision of meaningful job training that will lead to suitable employment, as well as nceds-related payments to individuals participating in vocational training under the settlement. ${ }^{92}$

The ultimate success of the settlement, however, will not truly be known until it has been implemented and tested, and it is yet to be seen whether limited-

88. 20 C.F.R. \$617.2 (2005).

89. See 19 U.S.C. \$2296(e) (2000).

90. See Complaint at para. 11, Asociación de Trabajadores Fronterizos v. U.S. Dep't of Labor, No. 1:04-cv-00993 (D.D.C filed June 17,2004) (on file with author).

91. See Settlement Agreement, at \$2.3.8 (Available Training Courses in the LEP Project), available at http://www.citizen.org/documents/ATFMotionDismissandSettlement.pdf (last visited January 21,2006$)$.

92. Id. at $\$ 2.3 .3$. LEP Project Funding Dedicated for Use in the El Paso Area. 
English proficient Latinos nationwide will benefit. ${ }^{93}$ The approach carries with it potential pitfalls for people seeking vocational retraining in the future. Perhaps the greatest tangible risk is that training providers may foreclose workers who do not meet high education or language requirements for training programs from enrolling in their training altogether, based on suspicions the workers will not be able to meet the stated goal of job-readiness at an 80 percent wagereplacement rate at the completion of training. ${ }^{\text {.4 }}$ The operational parameters issued by the U.S. Department of Labor with regard to federal job training and employment specifically permit the training providers to set the criteria for determining an individual's eligibility to participate, and a determination of eligibility is not subjected to the federal Department of Labor's Common Measures policy. ${ }^{95}$ This risk that workers will be prescreened out of training opportunities is partly addressed in the Draft Training and Employment Guidance Letter issued in compliance with the settlement agreement, ${ }^{4,}$ which specifically allows that the 80 percent wage-replacement goal upon completion of training is a goal, not a requirement, noting that "it is not always feasible to train workers for suit-

93. One positive development is the U.S. Department of Labor's issuance of a Limited Fnglish Proficiency and Hispanic Worker Initiative. The Employment and Training Administration of the U.S. Department of Labor has announced $\$ 5$ million in available grants for development of training for individuals with limited-English proficiency and "Hispanic Americans, specifically, those who lack basic and occupational skills needed by high-growth occupations." Workforce Investment Act-Limited English Proficiency and Hispanic Worker Initiative, 70 Fed. Reg. 35,118, 35,118 (June 16, 2005). Unfortunately, the Department of Labor sanctions the notion that barriers to employment and training belong to the workers rather than a training system and implementing agencies and officials that erect the barriers, stating: "LEP individuals face critical challenges in their ability to perform self-sustaining work in the United States. The lack of English language skills impedes how LEP individuals communicate with employers, educators, and service providers." Id. at 35.119.

94. Department of Labor's Response to Plaintiffs' Motion for Summary Judgment at 19, Asociación de Trabajadores Fronterizos v. U.S. Dep't of Labor, No. EP-04-CA-400-FM (W.D. Tex Nov. 5, 2004) ("The result that individuals may receive no training is especially likely when the affected population has characteristics like those of the trade-affected population in El Paso: older workers with low literacy levels, low levels of English, and limited transferable skills.").

95. Guidance Letter No. 28-04, from Emily Stover DeRocco, Assistant Sec y, U.S. Dep t of Labor to all State Workforce Agencies and Liaisons 4 (Apr. 15, 2005), available at http://wdr. doleta.gov/directives/attach/TEG1.28-04.pdf.

96. Settlement Agreement, supra note 91, at \$ 2.4.1, Training and Employment Guidance Letter No. 13-05, from Emily Stover DeRocco, Assistant Sec'y, "Serving Participants under the Trade Adjustment Assistance (TAA) and North American Free Trade Agreement Transitional Adjustment Assistance (NAFTA-TAA) Programs" (Feb. 2, 2006), available at http://wdr. doleta.gov/ directives/attach/TEGL13-05.pdf (Guidance Letter). 
able employment." But this allowance is the very allowance that resulted in an explicit waiver of the wage-replacement criteria for the El Paso workers, and it mirrors the stated reasons for denying the Money's workers in Pennsylvania access to training. The development of adequate tools for assessment of the worker's competencies that do not prejudice a candidate because of his limitedEnglish proficiency and the subsequent development of an individual employment plan therefore become critical. Without a comprehensive assessment upon which to base training decisions, it will be difficult to later assess whether lack of required competencies for access into the current job market served as a pretext for denying limited-English proficient, but otherwise qualified, workers access to vocational training. Monitoring of both the training outputs and the entire scope of services provided, as well as the criteria and methods employed for developing individual employment plans and training programs from the moment the worker is first identified as a dislocated worker through to the time the worker is reemployed, is therefore essential. ${ }^{1 \nmid}$ Looking beyond the El Paso workers, it will be important to closely monitor the populations adversely affected by the mathematical calculations of training outputs to identify whether those who are refused training, or who participate in a program, yet continue to fail to meet the training output goals are failing not because of objective performance measures but because of unlawful and invidious racial, national origin, and/or ethnic discrimination.

\section{The Role of "Citizenship" and Identity in Recognizing the Rights of Dislocated Immigrant Workers}

While the ATF settlement makes great strides on behalf of limited-English proficient immigrant workers, the successful integration of limited-English proficient immigrant workers into the changing labor market economy will ultimately depend upon recognition of those workers as legal, permanent, and valued members of society. The Department of Labor's dismissal of the Money's

97. Guidance Letter, supra note 95, at $\$ 4 . a$.

98. Texas Workforce Comm'n, Integration of Trade Services for Dislocated Workers: A Compremensive Guide (2005), included in the settlement agreement, provides a useful framework for addressing the specifics of implementation, methods, and criteria for provision of trade services for dislocated workers, particularly with regard to those who are limited-English proficient. Exhibit $\mathrm{C}$ of the Settlement Agreement, supra note 91. While the Guide is for the Texas Workforce Commission, it is one that could benefit other jurisdictions as well. 
workers complaint of unlawful discrimination and ATF's counsel's reliance on a facially neutral mathematical approach to challenging the woeful training delivered by the Texas Workforce Commission raise questions about the efficacy of antidiscrimination laws to address the rights of limited-English proficient immigrants. Professor Perea's argument, discussed above in Part II.B, for ethnicity and ethnic traits to be recognized by antidiscrimination statutes provides an alternative to our current scheme of discrimination laws that recognizes that people are discriminated against because of their otherness. But that otherness takes on an additional role when addressing the membership rights of immigrants, particularly immigrants who are limited-English proficient.

The discrimination the Money's workers and the ATF members encountered in trying to obtain vocational training benefits-benefits that would allow them to obtain fuller membership in their broader community-are based in long-standing perceptions of Latino immigrants, and, specific to these cases, the history of Mexican migration to the United States. That history, dating back to the 1920 s, informs perceptions of Euro-Americans as citizens, and Mexican immigrants as "alien." In an in-depth account of immigration to the United States, Mae Ngai notes, "Euro-Americans perceived Mexicans as foreigners even though the majority of the Anglos themselves had also migrated to the Southwest during the same period. 'Foreignness' was a racialized concept that adhered to all Mexicans, including those born in the United States, and carried the opprobrium of illegitimacy and inferiority." ${ }^{+10}$ That "foreignness" reveals itself, among other ways, through language. ${ }^{\text {inl }}$

Nearly a full century later, comments from Berks County Commissioner Mark C. Scott recall the early twentieth century notions about Mexican immi-

99. See Mae M. Ngai, Impossible Stejects: Illegal Aliens and the Making of Modern America 130-35 (2004). Similar arguments have been made vis-à-vis other immigrant groups, specifically persons of Asian ancestry. recognizing how notions of citizenship are rooted in race. See, e.g. Leti Volpp, The Citizen and the Terrorist, t9 UCLA L. Rev. 1575 (2002).

100. NGar supra note 99, at 131-32: see also Leti Volpp, Imposible Subjects: Illegal Aliens and Alien Citizens, 103 Mich. L. Rev. 1595 (2005) (reviewing NGal, supra note 99).

101. See Michelle Lamont, The Diginity of Working Men: Morality and the Bolndaries of Race, Class, and Immgration $\$ 812(0)($ ) ("To the extent that white workers drew boundaries against this group, these boundaries ... mostly targeted Hispanics. The latter's unwillingness to learn English was described as their greatest failing: it brings down the entire country and poses a direct threat to the workers for whom national identity stands as a symol of pride and as one of the few high-status signals they can claim."). 
grants described by Ms. Ngai. ${ }^{\text {tw. }}$ Commenting on his reason for voting against funding the part-time salary of a bilingual case manager for the Money's workers, he stated: "|The Money's workers/are not American citizens. So why are we doing this? I can't believe we educate Mexican nationals when we're having trouble doing it for our own people... You ve got to do something. It's unbelievable." Mr. Scott explicitly used national origin as the basis to make assumptions of citizenship status, which then served as rationale for determining the Money's workers are not worthy to participate fully in the social and political rights of the community. ${ }^{104}$ As evidenced by Mr. Scott's comments and as implicated by the failure to provide language-accessible services, the role that perceived alienage plays in discrimination against Mexican-born immigrants, as well as other immigrant groups, ${ }^{1,15}$ is undeniable. ${ }^{1.6 .}$

102. See Volpp, supra note 100, at 1597 ("Today the conflation of the racial identity "Mexican" with the term 'illegal alien' is indisputable. The two terms completely subsume one another in a way that aligns with our everyday understanding of immigration control — even while this does not trach empirical fact.").

103. Young, supra note 27.

104. In a battle with the U.S. Department of Justice over the provision of bilingual ballots and other actions to ensure that the Voting Rights Act was not violated as it applies to the Spanishspeaking citizens in Berks County, County Commissioner Timothy Reiver indicated his belief that English language skills were necessary to the County's socioeconomic success. Stating his belief that providing bilingual ballots would be counterproductive, he stated: "We need to move beyond that. Berks County is an English-speaking county. People are not going to access better paying jobs and better opportunities here if they don t learn to speak English." Dan Kelly, Berks to Fight Order to Help Latino Voters, Reading Fagle (Pa.), Dec. 20, 2002, at Al.

105. Even within specific ancestral groups, there may be discrimination based on the distinctions individuals make about their legal and socioeconomic status. See Johnson, supra note 50, at 201-05 (noting the divisions between Mexican-Americans and Mexican immigrants on the issue of immigration); id. at 204 (recognizing that "Mexican-Americans and Mexican immigrants at some level have different group identities and speak with different voices"'). See also Kevin R. Johnson, The End of "Civil Rights" as We Know It?: Immigration and Civil Rights in the New Millennium, 49 UCLA L. Rev. 1481 (2002) (discussing the role of race at the intersection of immigration law and civil rights law).

106. Cf. Ruben J. Garcia, Across the Borders: Immigrant Status and Identity in Law' and LatCrit Theory, 55 Fla. L. Rev. 511, 523 (2003) ("Statements like 'go back where you came from' are racially coded, yet a jury may see only 'immigrant' in such language. Discrimination may have yet another back door, and these ills will exist in legal darkness without any remedy."). This was also seen in Berks County, Pennsylvania in the public and legal fight over the provision of bilingual ballots. In March 2003, the U.S. District Court for the Eastern District of Pennsylvania issued a preliminary injunction mandating Berks County take measures to ensure that the county would not violate the Voting Rights Act as applied to the limited-English proficient citizens of Puerto Rican descent. United States v. Berks County, 250 F. Supp. 2d 525 (E.D. Pa. 2003). In its decision, the Court 
Language becomes a key marker used to identify an individual as an immigrant, and therefore as "alien." The requirement that immigrants demonstrate proficiency in English in order to obtain citizenship ${ }^{1+1}$ illustrates the role language plays in gaining full social and political membership rights in the United States. Language-based discrimination reveals underlying hostility and prejudices against perceived outsiders ${ }^{105}$ - those who reveal their otherness through their inability to speak and understand English. ${ }^{109}$ As noted by the Ninth Circuit in Yniquez v. Avizonans for Official English: "Since language is a close and meaningful proxy for national origin, restrictions on the use of languages may mask discrimination against specific national origin groups or, more generally, conceal nativist sentiment." 110

The failure of Mexican-born immigrants to learn English is often treated in the public discourse as an intentional act to maintain "foreignness," and a refusal to assimilate that is considered rude and an insult to the United States and all immigrants who have come before them, learned English, and become "Ameri-

noted the "significant socioeconomic inequality" suffered by the Hispanics in Reading, Pennsylvania. Id. at 528. The Court also noted the hostile attitude Spanish-speaking citizens faced at the polls, quoting one poll worker as saying: "This is the U.S.A.- Hispanics should not be allowed to have two last names. They should learn to speak the language and we should make them take only one last name." Id. at 529. In the Court's later judgment against Berks County, another poil worker is quoted as saying: "Dumb Spanish-speaking people... I don't know why they"re given the right to vote." United States v. Berkis County, Pa., 277 F. Supp. 2d 570, 575 (E.D. Pa. 2003).

107. 8 U.S.C. $\$ 1423(2000)$.

108. See Sandrino-Glasser, supra note 62, at 104-07 (noting that even after having been granted citizenship, Mexicans and Puerto Ricans "were not included in the imagined community, instead they were racially perceived as 'foreign Others"'). See also, Michèle Lamont, Working Men's Imagined Communities: The Boundaries of Race, Immigration, and Poverty in France and the Linted States, in The Postnational Self: Belonging and Identity 186 (Ulf Hedetoft \& Mette Hjort eds., 2002) (noting that "li|n the mind of many American workers, social and cultural membership remains largely equated with being white and being at least lower-middle or working class"). Immigrants, she notes, particularly Caucasian immigrants, "who attempt to achieve the American dream are easily made part of 'us'." Id.

109. According to Edward McCann. Director of the Berks County Workforce Investment Board, "|The Money's Mushroom workers| face almost insurmountable barriers to them working at any really self-sustaining level in the United States of America." Mary E. Young, Laid-Off Berk: County, Pa., Mexican Produce Workers Claim Bias in Lausuit, Reading Eagle (Pa.), Mar. 14, 2003 (on file with author). Implicit in Mr. McCann's comment is his belicf that the Money's workers would be best served if they returned to Mexico, despite his ack nowledgment that they are legal permanent residents who have lived and worked in the area for many years.

110. 69 F.3d 920, 947-48 (9th Cir. 1995), vacated on other grounds, 520 U.S. 43 (1997). 
can." 11 Studies counter, however, that the rate of assimilation and the rate of English-language learning among today's immigrants is no different than that of immigrants in the past. "Furthermore, as Professor Bill Ong Hing has put forth, in arguing for a new approach to cultural pluralism held together by a core set of values and a broader definition of what it means to be American:

We cannot expect those at the margin to buy into a core without the commitment of the power structure. Immigrant adaptation. and creating a common core, must be viewed as a dual responsibility of the immigrant and the mainstream."

The concept of dual responsibility recognizes the hypocrisy of those who deny meaningful job training to limited-English proficiency workers. Rather than embrace the workers' desire for retraining, so they can adapt to the changing labor needs of their community, those seeking to isolate the workers in remedial education and training programs deprive the workers of the opportunity they have sought to take hold of their American identity. The experiences of the Money's workers and the ATF members in many ways support Professor Perea's argument that English is used to render Latinos invisible, an invisibility that he defines

111. See Lamont, supra note 108, at 188-89 (noting that the "failure to assimilate" and the perceived "lack of desire to learn English" interferes with immigrants full integration, and acknowledging that the "recent debates about Latino immigration may suggest that we have entered a new phase of xenophobia"). Professor Diaz Cameron has argued: "In the immigration model, the superior people are still White, but now what makes them superior is a type of nativism characterized by their Anglo, English-speaking, monolingual background. The superior people, with the Statue of Liberty as their emblem, welcome by invitation non-Anglo, non-English-speaking inferiors, especially those from continental Europe, but only so long as they promise to assimilatethat is, try to become more like Anglo English-speakers and less like the folks they used to be." Cameron, supra note 55 , at 1358 . He further states: "Latinos' persistence in maintaining cultural ties, especially language, is often fodder for conservatives' cannons |sic| against the immigration of Mexicans and Latin Americans to the United States. Properly understood, however, this 'refusal to assimilate' is just another way of complaining that we refuse to remain invisible." Id. at 1374 (footnote omitted).

112. See Stina Santiestevan, Use of the Spamsh Language in the United States: Tiends, Challenges, and Opportunities (1991), available at http:/www.ericdigests.org/pre-9221/spanish.htm; Richard Alba, Bilingualism Persists, But English Still Dominates, Migration Info. Source, Feb. 1, 2005, available at http://www.migrationintormation.org/Feature/display.cfm?'id =282.

113. Bill Ong Hing, Beyond the Rhetoric of Asimilation and Cultural Pluralism: Addressing the Tension of Separatism and Conflict in an Immigration-Driven Multiracial Society, 81 CAL. L. REv. 863, 870 (1993). 
as "a relative lack of positive public identity and legitimacy." "114 Government agencies implementing vocational training programs must take some responsibility for the relegation of the Latino workers to remedial education courses rather than meaningful vocational training. leading to the continued-or, in some cases, furthered-ghettoization of the Latino workers denied the opportunities to fully integrate themselves into mainstream American society.

The successful implementation of the ATF settlement and development of meaningful bilingual training programs can serve as a momentous step forward. beyond the relegation of limited-English proficient immigrant workers to lowpaying, invisible jobs in the service industry, toward recognition of Latinos' competitiveness in the changing labor force and the added value that their Spanishlanguage abilities provide. ${ }^{115}$

\section{Conclusion: Devising a More Comprehensive Approachi Toward Integrating Immigrant Workers}

The experiences of the ATF workers in Texas and the Money's workers in Pennsylvania are emblematic of the struggles endured by immigrant populations throughout the United States secking to realize the same American dream as previous generations of immigrants have. As immigrant workers struggle to realize that dream in the context of a changing global economy, advocates and workers who engage the system established to provide training assistance and to provide workers with a competitive edge must strategize around broader notions of membership and the role of language. And they must engage policy makers, courts, and federal and state agencies in a dialogue that moves beyond the traditional civil-rights-cra paradigm of black and white to recognize the complexity of discrimination that must be overcome to allow for fuller integration of immigrants into our society.

A need for a deeper and more nuanced understanding of factors that interfere with the workers ultimate goal of attaining stability and membership in the community is needed. When English language, education, and technical skills

114. Perea, stura note 61 , at 966.

115. Professor Perea argues that "invisibility ... is created in several ways. Sumerimes we are rendered invisible through the absence of public recognition and portrayal. Sumetimes we are sikenced through prohibitions on the use of Spanish. Sometimes we are rendered politically invisible, or nearly invisible, through the attribution of forcignness. what 1 shall call symbolic deportation:". Id. 
are used as barriers toward achieving that goal, they reveal underlying discrimination that works against the rising visibility and public legitimacy of Latinos as full possessors of social, economic, and political rights. The struggles of the ATF members and the Money's workers may inform discussions about the treatment of immigrants throughout the United States and beyond. Labor migration is not a phenomenon unique to the United States, and their experiences can serve to inform other immigrants and those working on their behalf. The hard-won settlement for the ATF members may serve as a model for providing the necessary tools and opportunities for achieving full citizenship status - status that implies recognition as legitimate members of society. But the success of the model may depend on an acknowledgement of the breadth of discrimination faced and the challenges multilayered discrimination poses. 